\title{
Rancang Bangun Website Rekam Medis Elektronik di Fasilitas Pelayanan Kesehatan Praktik Dokter
}

\author{
${ }^{1}$ Nurhayati*, ${ }^{2}$ Yunita Wisda Tumarta Arif, ${ }^{3}$ Ahmad Yusron Yunizar \\ ${ }^{1,2,3}$ Program Studi Rekam Medik dan Informasi Kesehatan, Fakultas Ilmu Kesehatan, Universitas Duta \\ Bangsa \\ *nurhayati@udb.ac.id
}

\begin{abstract}
Abstrak
Rekam medis elektronik mencatat rekam medis yang tersimpan secara elektronik yang isinya meliputi data personal, data demografis, data sosial, data klinis / medis. Pengolahan dokumen rekam medis di fasyankes praktik dokter masih dilakukan secara manual, di mulai dari pendaftaran pasien, penulisan riwayat pemeriksaan, dan penyimpanan dokumen rekam medis. Salah suatu upaya untuk mengatasi kendala tersebut yaitu dengan membangun website Rekam Medis Elektronik. Metode pengembangan website menggunakan sistem development life cycle. Rekam Medis diproses dari input data pasien, data diagnosa, data tindakan, data obat, data petugas, data pendaftaran, data pemeriksaan. Kemudian data tersebut diolah untuk menghasilkan laporan antaralain data pasien, dan data pemeriksaan. Website rekam medis elektronik yang digunakan dapat mempermudah pengolahan data rekam medis.
\end{abstract}

Kata Kunci: rekam medis elektronik, website, fasyankes

\section{Abstract}

Electronic medical records record electronic medical records which contain personal data, demographic data, social data, clinical / medical data. Processing of medical record documents at doctor's practice health facilities is still done manually, starting from patient registration, writing examination history, and storing medical record documents. One of the efforts to overcome these obstacles is by building an Electronic Medical Record website. The website development method uses the development life cycle system. Medical records are processed from input patient data, diagnostic data, action data, drug data, officer data, registration data, examination data. Then the data is processed to produce reports, including patient data, and examination data. The electronic medical record website used can simplify the processing of medical record data.

Keywords: electronic medical record, website, health care facility

\section{PENDAHULUAN}

Fasilitas pelayanan kesehatan menyelenggarakan upaya pelayanan kesehatan, baik promotif, preventif, kuratif maupun rehabilitatif yang dilakukan oleh pemerintah, pemerintah daerah, dan/atau masyarakat. Keberadaan informasi yang cepat dan akurat akan mempermudah suatu fasilitas pelayanan kesehatan untuk memberikan pelayanan yang tepat sesuai dengan kondisi pasien.

Penyelenggaraan rekam medis dilakukan oleh unit rekam medis yang bertugas mengelola dokumen rekam medis pasien. Salah satu wewenang dokter praktek perorangan adalah menyelenggarakan rekam medis yang memenuhi standar (Depkes RI, 2006).

Dokter Praktek Perorangan dr.Iin Delfi Indraswarti.,M.Kes merupakan fasilitas pelayanan kesehatan yang menjadi studi kasus dalam penelitian ini. Pelayanan pasien sudah terjadwal dengan baik setiap hari. Dalam menyelenggarakan rekam medis pasien masih menggunakan rekam medis manual yang berupa formulir yang berisi identitas pasien dan diagnosa penyakit yang di catat secara manual oleh petugas. Masalah yang ditemui pada dokumen rekam medis pasien, yaitu terdapat beberapa item yang tidak terisi secara lengkap dan terdapat formulir yang hilang ataupun rusak sehingga petugas tidak bisa menemukan formulir yang hilang ataupun rusak dan mengakibatkan dokter tidak bisa mengetahui kondisi pasien sebelumnya. Pengelolaan rekam medis masih menggunakan rekam medis konvensional, padahal memiliki sumber daya manusia yang dipandang mampu mengoperasikan rekam medis elektronik.

Rekam medis elektronik bermanfaat sebagai gudang penyimpanan informasi secara elektronik mengenai status kesehatan dan layanan kesehatan yang di peroleh pasien sepanjang hidupnya. Selain itu,pengunaan rekam medis memberikan manfaat kepada dokter dan petugas kesehatan dalam mengakses informasi pasien yang pada akhirnya membantu dalam mengambil keputusan klinis.

Penelitian ini bertujuan membangun website rekam medis elektronik yang mampu melakukan pencatatan dan pengelolaan data rekam medis pasien pada fasilitas pelayanan kesehatan praktik dokter.

TINJAUAN PUSTAKA

Rekam Medis Elektronik 
Menurut Sudra (2014) Rekam medis elektronik yaitu rekam medis yang tersimpan secara elektronik yang isinya meliputi data personal, data demografis, data sosial, data klinis/medis selama proses pelayanan dari berbagai sumber data (multimedia) dan memiliki fungsi secara aktif untuk memberikan dukungan bagi pengambilan keputusan medis. Electronic Medical Record (EMR) sering dipertukarkan dengan computer-based patient record (CPR) untuk menyatakan suatu sistem berbasis komputer yang digunakan untuk mengelola informasi pelayanan pasien. Pemahaman rekam medis elektronik bukan sekedar memindahkan berkas atau formulir kertas dalam bentuk file komputer. Rekam medis elektronik memungkinkan berbagai informasi dari berbagai sumber dalam berbagai bentuk untuk disimpan, diolah, dikomunikasikan dan diambil dalam bentuk asli atau olahannya. Bagi instansi penyelenggara pelayanan kesehatan yang sudah menggunakan rekam medis elektronik maka dalam penyelenggaraan rekam medis untuk autentifikasi dalam rekam medis dapat menggunakan nomor identitas pribadi. Pemanfaatan rekam medis elektronik terutama adalah meliputi kepentingan pelayanan terhadap pasien, meliputi pelayanan klinik (medis) maupun administratif, pendidikan, penyusunan regulasi, penelitian, pengolahan kesehatan komunitas, dan penunjang kebijakan. Terdapat keuntungan yang didapatkan dengan menyelenggarakan rekam medis secara elektronik. Beberapa keuntungan yang didapat dari penyelenggaraan rekam medis elektronik adalah manajemen efisiensi data, aksebilitas data dan pengurangan waktu untuk pencatatan.

Rekam medis elektronik minimal harus memiliki kemampuan sebagai berikut :

1. Kemampuan mengidentifikasi seluruh informasi pasien yang dibentuk dan dikelola oleh sarana pelayanan kesehatan.

2. Kemampuan menyiapkan informasi pasien agar siapa digunakan oleh seluruh pemberi layanan yang bekerja di saranan pelayanan kesehatan.

3. Ketersediaan stasiun kerja yang dapat didayagunakan oleh setiap pelayanan layanan.

4. Ketersediaan sistem keamanan yang mampu melindungi informasi.

Penelitian Solikhah (2018) menunjukkan rekam medis elekronik dapat memberi informasi secara berkesinambungan mengenai riwayat pemeriksaan pasien, meminimalisir kerusakan dokumen kertas, dan meminimalisir tulisan yang tidak terbaca.

Penelitian Prawirodirjo,et al (2019) menunjukkan rekam medis elektronik meningkatkan pelayanan kesehatan di klinik dengan hasil rekam medis elektronik dapat mengurangi waktu pelayanan yang awalnya 5-8 menit menjadi 2-3 menit pada saat registrasi dan mempercepat pencarian rekam medis pasien rawat jalan saat melakukan kontrol kesehatan gigi.

Penelitian Arif, et al (2019) memperoleh hasil rekam medis elektronik memudahkan untuk memperoleh informasi yang cepat,tepat dan akurat demi meningkatkan kualitas pelayanan kesehatan dalam pendaftaran rawat jalan.

\section{Website}

World Wide Web atau www atau juga dikenal dengan website adalah salah satu layanan yang didapat oleh pemakai komputer yang terhubung ke internet. Web ini menyediakan informasi bagi pemakai komputer yang terhubung ke internet. Website atau situs dapat diartikan sebagai kumpulan halaman-halaman yang digunakan untuk menampilkan informasi teks, gambar diam atau gerak, animasi, suara, dan atau gabungan dari semuanya itu baik yang bersifat statis maupun dinamis yang membentuk satu rangkaian bangunan yang saling terkait dimana masingmasing dihubungkan dengan jaringan-jaringan halaman (hyperlink). Website atau situs juga diartikan sebagai kumpulan halaman-halaman yang digunakan untuk menampilkan informasi teks, gambar diam atau gerak, animasi, suara, dan atau gabungan dari semuanya, baik yang bersifat statis maupun dinamis yang membentuk satu rangkaian bangunan yang saling terkait, yang masing-masing dihubungkan dengan jaringanjaringan halaman (Feoh et al., 2015)

\section{Dokter Praktik Perorangan}

Berdasarkan Peraturan Menteri Kesehatan Republik Indonesia Nomor 2052/Menkes/Per/X/2011 Tentang Izin Praktik Dan Pelaksanaan Praktik Kedokteran menyatakan praktik kedokteran adalah rangkaian kegiatan yang dilakukan oleh dokter dan dokter gigi terhadap pasien dalam melaksanakan upaya kesehatan, pasal 20 menyebutkan Dokter dan Dokter Gigi yang telah memiliki SIP berwenang untuk menyelenggarakan praktik kedokteran, yang meliputi antara lain:

a. mewawancarai pasien;

b. memeriksa fisik dan mental pasien;

c. menentukan pemeriksaan penunjang;

d. menegakkan diagnosis;

e. menentukan penatalaksanaan dan pengobatan pasien;

f. melakukan tindakan kedokteran atau kedokteran gigi;

g. menulis resep obat dan alat kesehatan;

h. menerbitkan surat keterangan dokter atau dokter gigi;

i. menyimpan dan memberikan obat dalam jumlah dan jenis yang sesuai dengan standar; dan

j. meracik dan menyerahkan obat kepada pasien, bagi yang praktik di daerah 
terpencil yang tidak ada apotek (Menteri Kesehatan Republik Indonesia, 2011).

\section{METODE}

Jenis penelitian adalah penelitian kualitatif , metode penelitian deskriptif. Variabel dan definisi operasional penelitian meliputi:

Tabel 1. Variabel dan Definisi Operasional

\begin{tabular}{|c|c|c|}
\hline No & Variabel & Definisi Operasional \\
\hline 1 & $\begin{array}{l}\text { Alur } \\
\text { prosedur } \\
\text { Pencatatan } \\
\text { dokumen } \\
\text { rekam } \\
\text { medis } \\
\text { pasien } \\
\text { praktek } \\
\text { dokter }\end{array}$ & $\begin{array}{l}\text { Tata cara yang digunakan } \\
\text { dalam proses pendaftaran } \\
\text { sampai pasien pulang }\end{array}$ \\
\hline 2 & $\begin{array}{l}\text { Pengelolaan } \\
\text { data } \\
\text { dokumen } \\
\text { rekam } \\
\text { medis } \\
\text { pasien } \\
\text { dokter } \\
\text { praktek }\end{array}$ & $\begin{array}{l}\text { Kegiatan yang dilakukan } \\
\text { untuk mencapai atau } \\
\text { menjadikan data lebih } \\
\text { bermanfaat dari data } \\
\text { sebelumnya yaitu menjadi } \\
\text { sebuah informasi, sehingga } \\
\text { pengelolaan data dokumen } \\
\text { rekam medis berupa data } \\
\text { pasien, data diagnosa yang } \\
\text { hasilnya berupa formulir } \\
\text { rekam medis pasien dan } \\
\text { informasi yang lain } \\
\text { dibutuhkan }\end{array}$ \\
\hline 3 & Data pasien & $\begin{array}{l}\text { Data pasien menyimpan dan } \\
\text { mencatat data sosial pasien } \\
\text { meliputi nama,norm,umur, } \\
\text { jenis kelamin,alamat }\end{array}$ \\
\hline 4 & $\begin{array}{l}\text { Data tenaga } \\
\text { kesehatan }\end{array}$ & $\begin{array}{l}\text { Meliputi kode tenaga } \\
\text { kesehatan, nama tenaga } \\
\text { kesehatan, profesi, jenis } \\
\text { kelamin, alamat dan nomor } \\
\text { telepon. }\end{array}$ \\
\hline 5 & $\begin{array}{l}\text { Data } \\
\text { tindakan }\end{array}$ & $\begin{array}{l}\text { Data yang mencatat dan } \\
\text { menyimpan jenis tindakan } \\
\text { yang diberikan kepada } \\
\text { pasien }\end{array}$ \\
\hline 6 & $\begin{array}{l}\text { Data } \\
\text { diagnosa }\end{array}$ & $\begin{array}{l}\text { Data yang mencatat dan } \\
\text { menyimpan data diagnosa } \\
\text { meliputi kode diagnos dan } \\
\text { nama diagnosa. }\end{array}$ \\
\hline 7 & $\begin{array}{l}\text { Data } \\
\text { pemeriksaan }\end{array}$ & $\begin{array}{l}\text { Data yang mencatat dan } \\
\text { menyimpan identitas pasien, } \\
\text { dokter yang memeriksa, } \\
\text { diagnosa obat dan tindakan. }\end{array}$ \\
\hline 8 & Data obat & $\begin{array}{l}\text { Obat adalah jenis obat yang } \\
\text { diberikan kepada pasien. }\end{array}$ \\
\hline 9 & $\begin{array}{l}\text { Data } \\
\text { pendaftaran }\end{array}$ & $\begin{array}{l}\text { Data yang mencatat dan } \\
\text { menyimpan } \\
\text { pendaftaran pasien }\end{array}$ \\
\hline 10 & $\begin{array}{l}\text { Rekam } \\
\text { medis }\end{array}$ & $\begin{array}{l}\text { Merancang rekam medis } \\
\text { elektronik dokter praktek }\end{array}$ \\
\hline
\end{tabular}

\begin{tabular}{|c|l|lr|}
\hline No & Variabel & \multicolumn{2}{|c|}{ Definisi Operasional } \\
\hline \multirow{5}{*}{} & elektronik & perorangan r untuk \\
& untuk & mengidentifikasi alur \\
& dokter & prosedur pencatatan \\
& praktek & $\begin{array}{l}\text { dokumen rekam medis } \\
\text { pasien,mengidentifikasi } \\
\end{array}$ & $\begin{array}{l}\text { pengelolaan data dokumen } \\
\text { rekam medis pasien }\end{array}$ \\
\hline
\end{tabular}

Subjek penelitian adalah praktek dokter perorangan dr.iin delfi indrawarti.,M.kes dan Petugas pada bagian pendaftaran. Objek penelitian adalah pencatatan dan pengolahan data rekam medis pasien.

Metode pengembangan sistem yang dilakukan meliputi:

1. Identifikasi dan Seleksi Proyek

Pada tahap ini peneliti melakukan survey pendahuluan untuk mengetahui alur dan prosedur pasien rawat jalan dan mengidentifikasi masalah yang ada pada bagian rekam medis di Praktek Dokter Perorangan dr.Iin Delfi Indraswati.,M.Kes. .

2. Inisiasi dan Perencanaan Proyek

Berdasarkan hasil survey pendahuluan, peneliti melakukan perencanaan untuk membangun website rekam medis elektronik.

3. Analysis (Tahap Analisis)

Peneliti melakukan pengumpulan informasi dengan cara observasi dan wawancara. Observasi dilakukan untuk mengetahui alur prosedur dan permasalahan yang terjadi di bagian rekam medis rawat jalan. Wawancara dilakukan terhadap petugas mengenai sistem yang digunakan, alur prosedur pasien rawat jalan dari pendaftaran sampai selesai pelayanan.

Berdasarkan hasil survey pendahuluan subyek penelitian membutuhkan website rekam medis elektronik untuk menggantikan sistem yang masih manual. Website menghasilkan informasi sesuai dengan kebutuhan, antara lain seperti laporan kunjungan pasien, laporan data pasien, laporan data diagnosa pasien, laporan data tindakan pasien, laporan data obat, laporan tenaga kesehatan, dan laporan data pembayaran.

$$
\text { 4. Design (Desain) }
$$

Tahapan desain sistem dapat dibagi menjadi dua, yaitu :

a. Desain Logis

Tahap desain logis menggambarkan kebutuhan mengenai data dan proses yang digunakan dalam sistem baru. Pada tahap ini peneliti melakukan perancangan sistem, antara lain :

1) Merancang Data Flow Diagram (DFD), mendesain database dan mengintegrasikan tabeltabel.

2) Perancangan input. Input dari sistem yang akan dibangun meliputi data pendaftaran, data 
pasien, data diagnosa, data tindakan, data obat, data tenaga kesehatan, dan data pembayaran.

3) Perancangan proses yang akan digunakan untuk merancang sistem rekam medis elektronik rawat jalan berbasis web.

4) Perancangan output. Output dari sistem yang akan dibangun meliputi laporan kunjungan pasien, laporan data pasien, laporan data diagnosa pasien, laporan data tindakan pasien, laporan data obat, laporan tenaga kesehatan, dan laporan data pembayaran.

b. Desain Fisik

Pada tahap ini peneliti merancang spesifikasi sistem yang akan dibangun meliputi mendesain dan mengintegrasikan tabel, mendesain antar muka pengguna, mendesain sistem antar muka, merancang dan membuat website rekam medis elektronik.

\section{HASIL DAN PEMBAHASAN}

\section{Alur Website Rekam Medis Elektronik Praktik Dokter}

Dimulai dari pasien datang ke tempat pendaftaran. Apakah pasien merupakan pasien baru jika iya maka pasien ditanya bawa kartu berobat atau tidak, jika membawa minta kartu berobat maka dapat mencatat nomor rekam medis pada website dan dilakukan proses pendaftaran. Apabila pasien tidak membawa kartu berobat maka cari identitas pasien di database, jika data tidak ditemukan maka pasien tersebut merupakan pasien baru dan petugas menginputkan data pasien ke website dan membuatkan kartu berobat untuk diberikan ke pasien. Apabila data ditemukan maka petugas dapat melanjutkan proses pendaftaran yang akan diinputkan ke sistem informasi lalu dokumen rekam medis dapat diambil. Dokumen rekam medis diserahkan ke petugas untuk mencatat pemeriksaan dan pemberian tindakan pada pasien.

Perancangan Alir Data

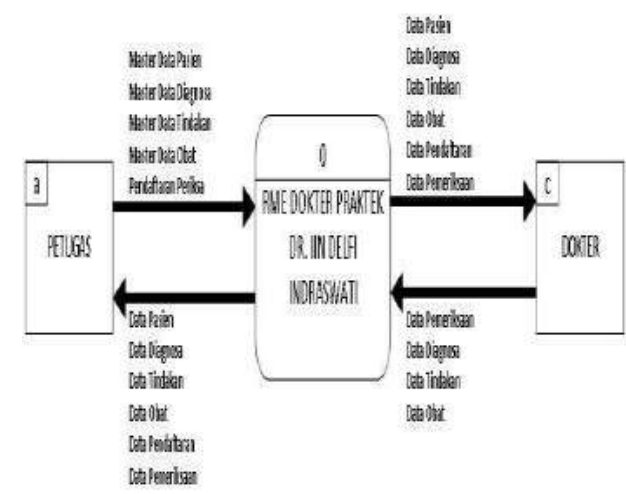

Gambar 1 Diagram Konteks Website Rekam Medis Elektronik

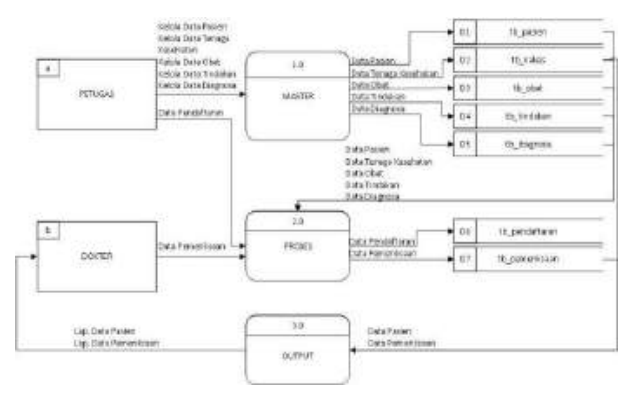

Gambar 2 Diagram level 0 Website Rekam Medis Elektronik Praktik Dokter

Perancangan Tabel

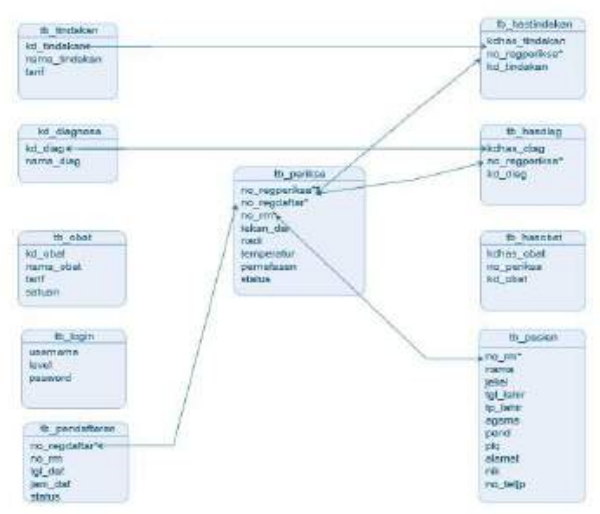

Gambar 3 Relasi Tabel

\section{Implementasi Website Rekam Medis} Elektronik Praktik Dokter

1. Implementasi Pengaktifan Program

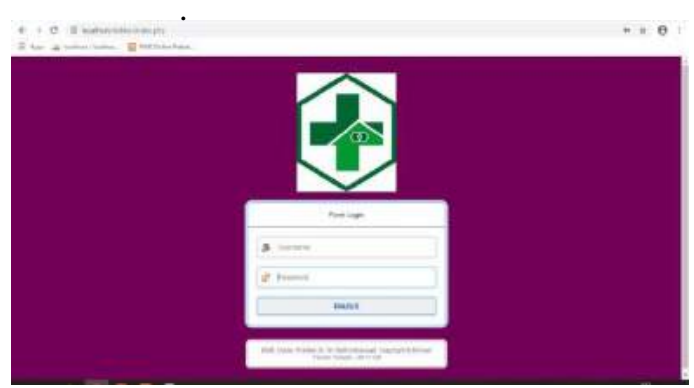

Gambar 4 Form Login

2. Implementasi Menu Utama

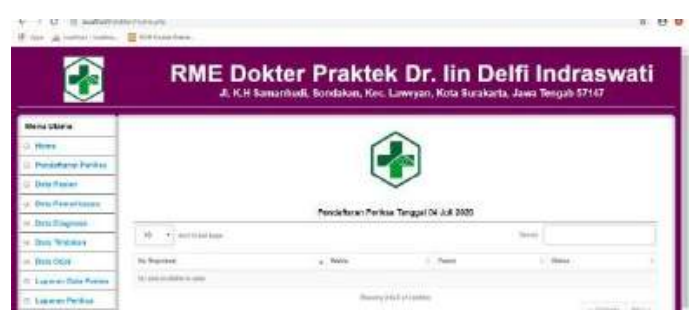

Gambar 5 Menu Utama 
3. Implementasi Master Data Pasien

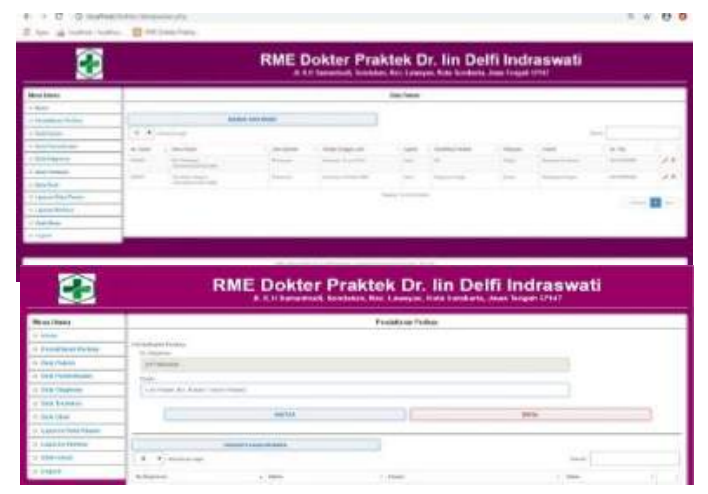

Gambar 6 Form Master Data Pasien

4. Implementasi Master Data Diagnosa

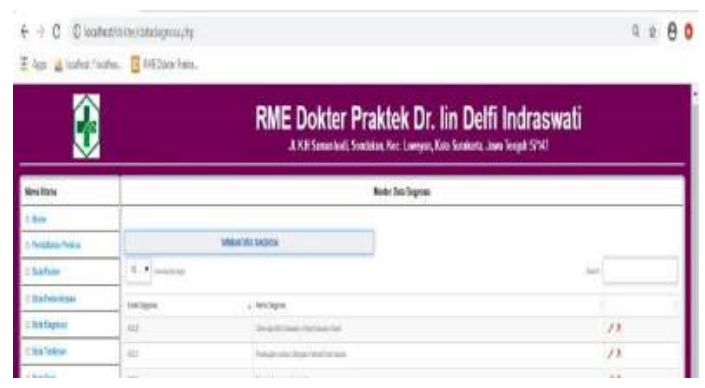

Gambar 7 Form Master Data Diagnosa

5. Implementasi Master Data Tindakan

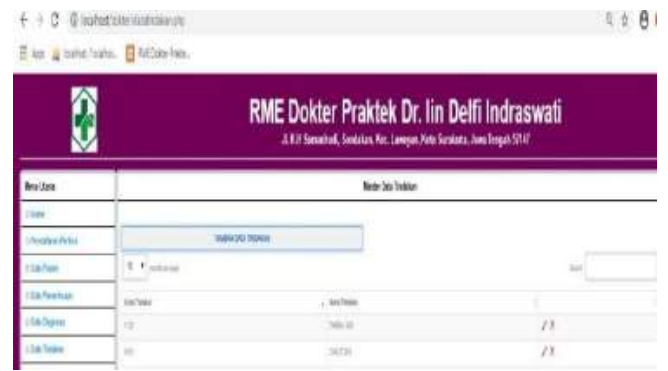

Gambar 8 Form Master Data Tindakan

6. Implementasi Master Data Obat

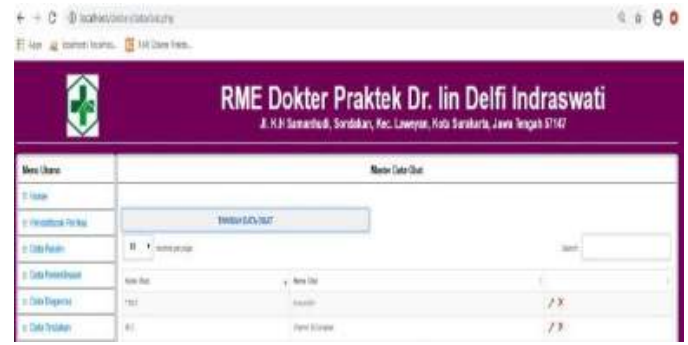

Gambar 9 Form Master Data Obat
7. Implementasi Master Data Petugas

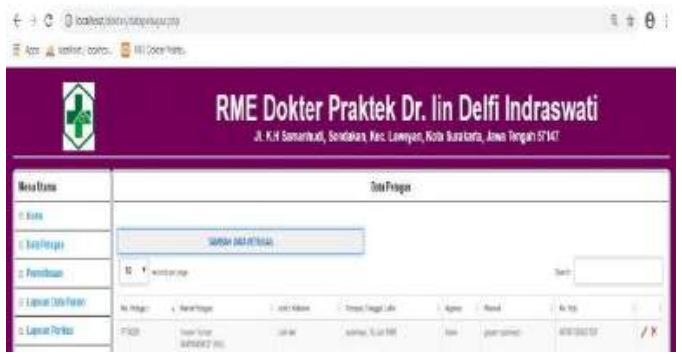

Gambar 10 Form Master Data Petugas

8. Implementasi Pemeriksaan

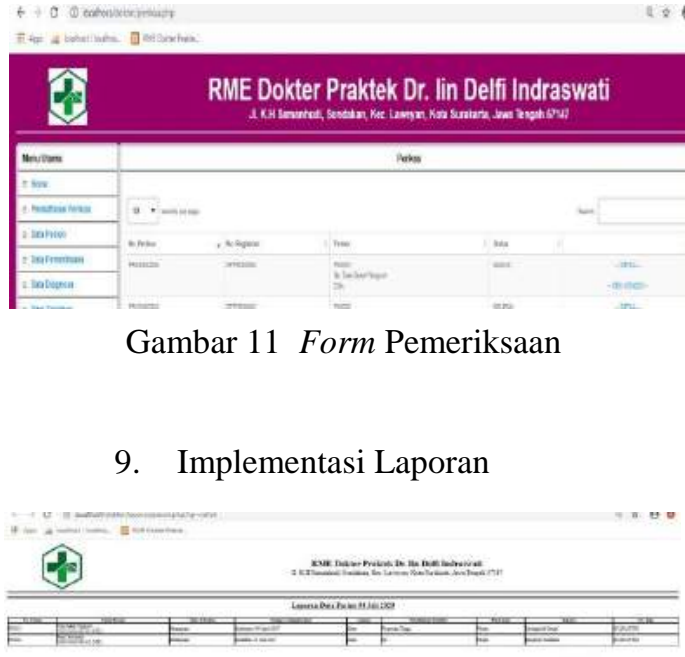

Gambar 12 Implementasi Laporan

\section{KESIMPULAN}

Website rekam medis elektronik yang dibangun dengan menggunakan bahasa pemrograman PHP dan basis data Mysql, dimana sistem ini memiliki kelebihan yaitu dapat mempercepat proses pendaftaran dan pengolahan data rekam medis pasien secara komputerisasi serta mempermudah petugas dalam membuat laporan

\section{DAFTAR PUSTAKA}

Arif, W.T., Suryadi, A. \& Meitasari, 2019. Komputerisasi Pendaftaran Pasien Rawat Jalan Berbasis Web Di Praktek Dokter. Jurnal Rekam Medis dan Informasi Kesehatan, 2(1), pp.1-6.

Depkes RI, 2006. Pedoman Penyelenggaraan Rekam Medis dan Prosedur Rekam. Jakarta: Direktorat Jenderal Bina Pelayanan Medik.

Feoh, G., Linawati \& Wirastuti, M.A.E.D., 2015. Indeks Kepuasan Pengguna Situs Web E-Gov Di Bali Dengan Metode EUCS Dan CSI. In Bali, S.S., ed. Konferensi Nasional Sistem \& Informatika 2015. Bali, 2015. STMIK STIKOM Bali.

Menteri Kesehatan Republik Indonesia, 2011. PERATURAN MENTERI KESEHATAN REPUBLIK INDONESIA NOMOR 
2052/MENKES/PER/X/2011 TENTANG ZIN PRAKTIK DAN PELAKSANAAN PRAKTIK KEDOKTERAN. [Online] Available at: HYPERLINK "https://ngada.org/bn671-2011.htm" https://ngada.org/bn671-2011.htm [Accessed 20 July 2019].

Prawiradirjo, M.A.D., Kartiko, H. \& Feoh, G., 2018. ERANCANGAN SISTEM INFORMASI REKAM MEDIS ELEKTRONIK RAWAT JALAN
BERBASIS WEB DI KLINIK GIGI BRIGHT SMILES BALI. urnal Teknologi Informasi dan Komputer, 4(1), pp.31-41.

Solikhah, A.O., 2018. Rekam Medis Elektronik Untuk Praktik Dokter Umum Di Klinik Amanah Medika Gondang Rejo Karanganyar. Karya Tulis Ilmiah. Surakarta: APIKES Citra Medika.

Sudra, R.I., 2014. Rekam Medis. Tangerang Selatan: Universitas Terbuka. 